\title{
Evaluating the Performance of Cuba's Sugarcane Basic Units of Cooperative Production During Their First Decade ${ }^{1}$
}

José Alvarez ${ }^{2}$

\section{Introduction}

From 1993 until 1995, the Cuban government implemented a series of new policies aimed at ameliorating the negative economic impacts brought about by the demise of the Soviet bloc (EDIS publication FE486, "Chronology of Cuban Reform Policies with Emphasis on Agriculture, 1993-1995", http://edis.ifas.ufl.edu/FE486). At the outset, this short period of economic reform was interpreted by some people in Cuba and abroad as the beginning of an economic transition. Time proved them wrong. It is now obvious that the Cuban leadership was more interested in gaining time to integrate the country into the global economy than in going beyond the enactment of a few timid market-oriented reforms. Despite that fact, the ten years that have elapsed since the announcement of those reforms deserve study since they provide ample evidence of the need to continue with the process that was initiated in 1993 and interrupted less than two years later.

The principal policy change announced in 1993 for the agricultural sector was the breakup of the state monopoly on land. To replace most state farms, a new form of agricultural organization was established: the Basic Unit of Cooperative Production (Unidad Básica de Producción Cooperativa, UBPC). EDIS publication FE487 ('Cuba's Basic Units of Cooperative Production", http://edis.ifas.ufl.edu/FE487) described the process of their creation and provided a general analysis of their early years.

The objective of this fact sheet is to provide a performance evaluation of the sugarcane UBPCs after their first ten years in operation. The evaluation follows standard measures such as production/productivity, revenue, cost, and profitability. It also revises the accomplishments of the UBPCs relating to their original goals and objectives. The fact sheet ends with a discussion of some of the factors that appear to be limiting the efficiency and profitability in Cuba's sugarcane UBPCs. As opposed to what was the norm in the past, comprehensive official data from Cuba's Ministry of Sugar (MINAZ) have recently become available for these cooperatives (MINAZ, 2003).

1. This is EDIS document FE562, a publication of the Department of Food and Resource Economics, Florida Cooperative Extension Service, Institute of Food and Agricultural Sciences, University of Florida, Gainesville, FL. Published June 2005. Please visit the EDIS website at http://edis.ifas.ufl.edu.

2. José Alvarez, Adjunct and Emeritus Professor, Department of Food and Resource Economics, Everglades Research and Education Center, Belle Glade, FL, Florida Cooperative Extension Service, Institute of Food and Agricultural Sciences, University of Florida, Gainesville, FL.

The Institute of Food and Agricultural Sciences (IFAS) is an Equal Opportunity Institution authorized to provide research, educational information and other services only to individuals and institutions that function with non-discrimination with respect to race, creed, color, religion, age, disability, sex, sexual orientation, marital status, national origin, political opinions or affiliations. U.S. Department of Agriculture, Cooperative Extension Service, University of Florida, IFAS, Florida A. \& M. University Cooperative Extension Program, and Boards of County Commissioners Cooperating. Larry Arrington, Dean 


\section{General Background}

At the end of 2003, ten years after the establishment of the UBPCs, the cooperative sector continued to be the dominant organization in Cuban agriculture (Table 1). The UBPCs, the Agricultural Production Cooperatives (CPAs), and the Cooperatives of Credit and Services (CCSs) accounted for 83.6 percent of the total agricultural area and for 90.6 percent of the sugarcane area. Since UBPCs control 75 percent of the total area in sugarcane, their performance is of utmost importance for the recovery of the Cuban sugar sector.

The 1993-2003 period shows an alarming decrease in the number of UBPCs, from the original 1,533 in January of 1994 to 885 in September of 2003 (MINAZ, 2003, p. 4). According to MINAZ (2003, p. 3), the closure of 648 units in the first decade was due to:

- mergers for economic reasons to take advantage of the existing infrastructure.

- mergers to increase their areas and strengthen their management.

- dissolutions for justified reasons, generally for the state's interest.

A simple linear regression analysis reveals that, between 1993 and 2003, the average rate of decline in the number of UBPCs was 60.27 units per year (Table 2). That decrease, for whatever reason, is cause for concern. The failure of Cuba's state farms was due to a great extent to their large size, which made them difficult to manage efficiently most of the time (Alvarez, 2004, pp. 76-77). An absolute decline of 42.27 percent is by no means trivial and this process should be observed, for it may signal, despite official reassurances to the contrary, a return to the state farm as the main unit of agricultural organization. This is not a farfetched observation since in the last few years actions by the Cuban government seem to indicate a reversal of the timid reforms enacted during 1993 to 1995.

\section{Evaluating Economic Performance}

\section{Measuring Agircultural Production and Productivity}

Three indicators to measure agricultural production and productivity are harvested area, yield, and total sugarcane production. The ten-year performance of UBPCs in this area is disappointing (Table 3). Using linear regression analysis, the average annual rate of decrease in harvested area was 38,800 hectares (Table 2). The average annual rate of increase in yields was only 0.5 tons per hectare (Table 2). Sugarcane production averaged 26 million tons during the ten-year period, although production in 2002-03 was only about half of the volume in the 1993-94 season (Table 3). The average annual rate of decrease in total production was around 860,000 tons during the study period (Table 2).

The analysis of the evolution of production per cooperative member provides useful insights into sugarcane productivity during the ten-year period. Individual productivity shows drastic declines, from 211.6 tons in 1993-94 to113.1 in 2002-03 (Table 4). The average rate of decline was 5.65 tons per member, per year (Table 2). It is interesting to note that, after years of declines, 203.7 tons per member were obtained in 2001-02, only to fall back to 113.1 in the last season of the study period (Table 4). How is that possible when the industry retained the most productive lands after the restructuring process conducted in 2002? (EDIS publication FE472, "The Current Restructuring of Cuba's Sugar Agroindustry", http://edis.ifas.ufl.edu/FE472.)

The situation of stagnant yields is more relevant under the current restructuring process. The production targets under the Tarea Alvaro Reynoso rest on achieving yields of 54 tons per hectare. Obviously, even with taking drastic measures, the goal of doubling agricultural yields will not be fulfilled for years to come. For example, if the current annual average increasing trend of 0.51 tons per hectare continues, it will take over 37 years to move from the 34.8 tons of the 2002-03 season to the goal of 54 tons per hectare under the Tarea Alvaro Reynoso. 


\section{Measuring Revenue, Cost, and Profitability}

The value of sugarcane crops (Table 4) reflects the production figures of Table 3 . The drastic change in the value of cane production in the 1998-99 season is due to an increase in the price of sugarcane from 14.32 to 21.65 pesos per ton (Table 5). The average annual rate of increase was slightly over 13 million pesos (Table 2). Little variation is shown in the value of total production, which includes payments for quality, compensations, and other incomes.

The absolute number of profitable units, which had been increasing and decreasing, fell drastically in the last season of the study period (Table 4). The average annual rate of decrease was 33 units (Table 2). However, the same variable, measured in percentages, shows a more encouraging situation. While the total number of units decreased every year, the percentage of profitable units increased in four of the ten years of the study period (Table 4).

The "total productivity" variable (expressed in Cuban pesos per member) shows better results in terms of an upward trend until the 2002-03 season when it fell over 50 percent (Table 4). The average annual rate of increase was 109 pesos per member (Table 2).

Production costs, sugarcane prices, and cost/price ratios are shown in Table 5. More or less stable production costs (with an average annual rate of increase of 1.15 pesos per ton of cane, as shown in Table 2) contrast with the extremely low sugarcane prices which do not cover costs. The resulting cost/price ratios are disappointing, since they increased every year except for 1998-99 (Table 5).

\section{The Original Four Basic Principles}

At the time of establishing the UBPCs and thereafter, the Cuban leadership has placed emphasis on their four basic principles (Gaceta, 1993, p. 15). A recent evaluation conducted by MINAZ (2003, pp. 8-12) is summarized below.

\section{Principle 1: Linking of the Man to the Land}

It was not until the end of 1995, during the celebration of the First National Encounter on the Linking of the Man to the Land, that 19 basic guidelines were defined. A slow progress was obtained until 2001, when MINAZ organized the labor force in Integral Cane Production Brigades (Brigadas Integrales de Producción de Caña, BIPC). Although MINAZ claims improvements in productivity and workers' income, the report only mentions an increase in workers' productivity in weeding in the last two years and a median income of 325.4 pesos in September of 2003. By acknowledging that "there is still much to be done," the report implicitly recognizes that the fulfillment of this principle has been at best quite disappointing.

\section{Principle 2: Self-Sufficiency of the Workers' Collective and Their Families, and the Improvement of Their Living Conditions}

The results in this area are also discouraging. Cuba's current lack of resources should not be an excuse since there are units that have reached acceptable results under the same conditions. Despite the increase in available land for food production after the agroindustry's restructuring at the end of 2003, the UBPCs were only fulfilling 77 percent of their viandas (taro, cassava, sweet potato, pumpkin) needs, followed by 46 percent for grains (rice and beans), and 9 percent for meat products. The report states that those results reflect deficient performance. From 1995 to 2003, the UBPCs built 20,780 houses (an average of slightly over one per year, per UBPC), with no houses being built in the last year of the report. Part of the blame, according to the report, falls on the country's current limitations and periodic hurricanes.

\section{Principle 3: Strict Relation of the Workers' Earnings to the Production Results Achieved}

Although payment based on production has been implemented with some variations in all UBPCs, it does not reach all workers. Achievements include an increase in median salary to 325.40 pesos per month, a monthly income in foreign exchange of US\$8.32 in La Habana province and US\$17.54 in Camagüey province, and better use of the 7.3-hour workday. 


\section{Principle 4: Autonomy of Management and the Administration of Their Resources with the Objective of Achieving Self-Sufficiency in the Productive Process}

The report (MINAZ, 2003) blames

administrators' lack of knowledge of economics and management as the major impediment in achieving the desired results. To correct that situation, MINAZ has established a series of schools in cooperatives and regions to train managers and administrators. Sugar officials blame the Directors of Enterprises because of their excessive tutelage and their insistence on exerting control over the UBPCs. Producers have also complained about the Directors' behavior as the main culprit in the lack of autonomy. Their role, according to the UBPCs' leaders, should be limited to orientation and assistance through contractual arrangements.

\section{Factors Limiting Efficiency and Profitability}

A series of factors are hindering the development of the sugarcane UBPCs into efficient and profitable units: material incentives, organizational changes, foreign investment, and research and extension.

\section{Material Incentives}

\section{Incentive 1: Sugarcane Price Payments}

The price of sugarcane was 14.32 Cuban pesos per metric ton until the 1998-99 season when it was raised to 21.65 pesos. This price does not even cover variable production costs. Cuban officials recognize that sugarcane prices must be increased, but they disagree on how much. A substantial increase is in order if more production is to be forthcoming.

\section{Incentive 2: Foreign Exchange Payments}

A new incentive system that allows bonus payments in foreign exchange for sugarcane agricultural workers was introduced in the 2000-01 zafra. Nova González (2004, p. 61) has described how the system works. Depending on performance, the worker can receive up to US\$15 (390 Cuban pesos) per month. Other monthly revenues in national currency include advanced payments (400 pesos), food for each family from self-provisioning plots (300 pesos), and compensations/government subsidies to the cooperative (300 pesos).

In the best possible scenario, monthly income would total 1,390 Cuban pesos. That figure, however, only represents a little over US\$53 - an insignificant amount considering Cuba's cost of living today, although much higher than the average salary of 254 pesos paid for several agricultural activities and the overall national average of 261 pesos in 2002 (ONE, 2003). It would be even lower if the 300 pesos in food are deducted since the workers and their families earn them by working in the self-provisioning plots.

About 93 percent of Cuba's total sugarcane production comes from cooperatives: UBPCs produce 76 percent, and CPAs and CCSs account for 17 percent (Nova González, 2004, p. 59). The current incentive system (including the extremely low price of sugarcane, currently at 21.65 Cuban pesos per metric ton) demands an overhaul to stimulate production.

\section{Incentive 3: Sugarcane Quality Payments}

It is hard to believe that Cuba's sugar agroindustry does not have a fully operational payment-for-quality system. The norms and guidelines are there, but the system does not work. Although individual cane samples are taken at the acopio (collection and cleaning) centers, they are mixed inside the mill. Thus, a grower's payment is not based on the weight of his own cane sampled at the acopio center, but on the average sucrose content of all the sugarcane milled. Efficient growers are thus penalized by the low sucrose content of inefficient producers. This is discouraging for the efficient grower. Payment-for-quality is enforced in almost all the sugarcane-producing countries of the world, and Cuba should not be an exception.

\section{Organizational Changes}

\section{Change 1: Autonomy}

Even ten years after their creation, UBPCs still do not enjoy full autonomy. The official reasons were summarized earlier in this paper. Needless to say, 
autonomy is badly needed, and lip service will not do. It is hard to believe that the Cuban leadership cannot enforce this legal provision. However, MINAZ's philosophy does not seem to convey a changing attitude. For example, in the ten-year report widely used in this paper (MINAZ, 2003), it is clearly stated that the state enterprises should continue "to exert state control over these [UBPCs] units" (p. 12).

\section{Change 2: Input and Output Markets}

Input and output markets should be liberalized. This policy change is a sine qua non for the sugar agroindustry to prosper. The inefficiencies and corrupt practices that result from the monopolistic control of the state over these markets are noticeable in Cuba. This is perhaps the area where Fidel Castro's recognition that "all openings have brought risks" applies best. Yet there is no apparent alternative solution.

\section{Foreign Investment}

Despite the different forms of foreign investment allowed by law, the Cuban government has systematically excluded the sugar agroindustry. Foreign capital was permitted for financing the purchasing of inputs in the mid- and late-1990s, and of by-products and derivatives. However, foreign investments in sugarcane milling and raw-sugar refining continue to be banned. For example, in June of 2004, a Business Meeting between MINAZ officials and potential foreign investors was held in Havana ("Diversification 2004: International Congress on Sugar and Sugarcane Derivatives"). There were 26 available businesses in the areas of sugarcane byproducts, sugar derivatives, and food production or processing, yet nothing was offered for milling or refining (Carpeta, 2004). The same picture is presented in a booklet of the Ministry for Foreign Investment and Economic Collaboration (CPI, 2003). That practice is negatively impacting the industry. Cuba's sugar agroindustry is in desperate need of capital, which Cuba does not presently offer.

\section{Research and Extension}

Cuba has an impressive number of extremely well qualified scientists at all levels in universities, ministries, and other governmental agencies. The amount and quality of research related to the sugar agroindustry is quite impressive. The problem is that, most of the time, valuable results are lost in a multitude of bureaucratic layers. On other occasions, recommendations cannot be implemented because the country lacks the resources to do so. The predominant problem, however, rests on the preference that Cuba's leadership currently places on politics over science in their decision-making process.

Cuba's Extension Service for sugarcane is organized under the Ministry of Sugar's National Institute of Sugarcane Research (Instituto Nacional de Investigaciones de la Caña de Azúcar, INICA). Its dual research/extension role is of recent vintage and has grown to become a remarkable organization. Its Scientific-Technical Specialized Service Unit is comprised of three departments: the Fertilizer and Amendment Recommendation Service (SERFE), created in 1996; the Variety and Seed Service (SERVAS), implemented in 1998; and the Phytosanitary Service (SEFIT), operational in Matanzas in 2000 (Campos Asín et al., 2003, pp. 35-36). The Institute also deals with technology transfer, technological innovation, training, and the dissemination of knowledge (Sulroca et al., 2004, p. 9). Extension is ready to expand and should play an important role in the process of transferring technology, not only from INICA, but also from other research organizations.

\section{Conclusion}

Most Cuban sugar specialists agree on the need to increase sugarcane supply as the fundamental step in advancing the Tarea Alvaro Reynoso. The sugarcane supply system, which collapsed at the end of the 1980s, has yet to recover. The priority of Cuba's sugar agroindustry should be the replacement of vastly depopulated sugarcane areas with productive fields. It appears that the best way to achieve that is through the extensive use of material incentives. This fact sheet has examined some components of an incentives system in need of an overhaul. Ten years ago, two Cuban authors put it in a revealing context:

When this man goes to the field without worries because his food and that of his family is secured; sees his basic needs solved; when 
he feels he is the owner of the fruits of his labor; when his income is related to his production; when his own actions are the ones that solve the collective's problems; when he feels his work is socially acknowledged; finally, when the basic principles for which the UBPCs were created are fulfilled, we are convinced that there will be more sugarcane (Jústiz García and Díaz Pérez, 1995, p. 16).

\section{References}

Alvarez, José. 2004. Cuba's Agricultural Sector. Gainesville, FL: University Press of Florida.

Campos Asín, Jacinto, Rolando González Acosta and Dolores Piñón Gómez. 2003. La Introducción de Resultados de la Investigación en la Agricultura Cañera a Través de los Servicios Científico-Técnicos del INICA. Cuba \& Caña 1: 35-38 (Instituto Nacional de Investigaciones de la Caña de Azúcar, Ciudad de la Habana, Cuba).

Carpeta de Negocios. 2004. Encuentro de Negocios, Diversificación 2004, La Habana, Cuba (June 16-17).

CPI (Centro de Promoción de Inversiones). 2003. Oportunidades para la Inversión Extranjera en Cuba. La Habana: Ministerio para la Inversión Extranjera y la Colaboración Económica (March).

Gaceta Oficial de la República. 1993. La Habana, Cuba, September 21.

Jústiz García, Elizabeth and Hilda Díaz Pérez. 1995. Resumen de los Principales Resultados de la Investigación Socio-económica Dirigida a las Unidades Básicas de Producción Cooperativa Cañeras del País Durante 1994. Colectivos

Laborales de Nuevo Tipo: Resumen de Investigaciones Sobre las UBPCs, edited by Polo Científico de Humanidades, pp. 10-16. La Habana: Prograna Flacso, Universidad de la Habana.

MINAZ. 2003. Informe Resumen del los Resultados Alcanzados por las UBPCs Cañeras en el Período 1993-2003. 2003 Ministerio del Azúcar and Sindicato Nacional de Trabajadores Azucareros. La Habana, Cuba (October 31).
Nova González, Armando. 2004. La UBPC y el Cooperativismo en la Agricultura Cubana, 1993-2001. In 15 Años. Centro de Estudios de la Economía Cubana, edited by Colectivo de Autores, pp. 51-78. La Habana, Cuba: Editorial Félix Varela.

ONE (Oficina Nacional de Estadísticas). 2003. Anuario Estadístico de Cuba, 2002. La Habana, Cuba.

Sulroca, Federico, Roberto Quintero, and Juan Carlos Figueroa. 2004. Las Cooperativas en la Agricultura Cañera Cubana. Paper presented at the First Seminar of Sugarcane Departments at Cuban Universities. Universidad de la Habana, Cuba (June 10-11). 
Table 1. Land under sugarcane by tenure and type of agricultural organization in Cub, excluding dispersed farmers, December of 2003.

\begin{tabular}{|c|c|c|c|c|c|c|c|c|c|}
\hline \multirow[t]{2}{*}{ Area } & \multicolumn{4}{|c|}{ Cooperative Sector } & \multicolumn{4}{|c|}{ State Sector } & \multirow[t]{2}{*}{ Total } \\
\hline & UBPC & CPA & CCS & Total & Farm & Enterprise & Usufruct & Total & \\
\hline & \multicolumn{9}{|c|}{ thousand hectares } \\
\hline Agricultural & 1283.7 & 299.0 & 128.4 & 1711.1 & 258.3 & 51.3 & 25.9 & 335.5 & 2046.6 \\
\hline In Cane & 796.1 & 147.5 & 18.3 & 961.9 & 94.5 & 4.6 & 0.2 & 99.3 & 1061.2 \\
\hline Nonagricultural & 143.9 & 39.8 & 17.5 & 201.2 & 32.7 & 21.9 & 2.9 & 57.5 & 258.7 \\
\hline Total & 1427.6 & 338.8 & 145.9 & 1912.3 & 291.0 & 73.2 & 28.8 & 393.0 & 2305.3 \\
\hline
\end{tabular}

Table 2. Simple linear regression results of selected performance parameters in sugarcane UBPCs, 1993-94 through 2002-03.

\begin{tabular}{|cccccc}
\hline \hline Variable & Unit & Intercept & X Coefficient & P Value & Adjusted $\mathrm{R}^{2}$ \\
\hline Total number & one & 1403.07 & -60.27 & 0.000 & 0.788 \\
Harvested area & 1,000 hectares & 1038.77 & -38.79 & 0.005 & 0.595 \\
Yield & tons/hectare & 28.96 & 0.51 & 0.065 & 0.284 \\
Total cane production & million tons & 30.73 & -0.86 & 0.057 & 0.305 \\
Value of sugarcane & million pesos & 419.51 & 13.25 & 0.258 & 0.051 \\
Profitable units & number & 674.60 & -32.94 & 0.211 & 0.086 \\
Profitable units & percentage & 40.53 & 0.87 & 0.638 & 0.092 \\
Productivity in cane & tons/member & 215.27 & -5.64 & 0.080 & 0.251 \\
Total productivity & pesos/member & 3320.31 & 109.43 & 0.300 & 0.025 \\
Total cost & pesos/ton of cane & 18.00 & 1.15 & 0.016 & 0.480 \\
\hline \hline
\end{tabular}


Table 3. Harvested area, yield, and total production in sugarcane UBPCs, 1993-94 through 2002-03.

\begin{tabular}{|c|c|c|c|c|c|c|c|c|c|c|c|}
\hline Item & Unit & $\begin{array}{r}1993 \\
-94\end{array}$ & $\begin{array}{r}1994 \\
-95\end{array}$ & $\begin{array}{r}1995 \\
-96\end{array}$ & $\begin{array}{r}1996 \\
-97\end{array}$ & $\begin{array}{r}1997 \\
-98\end{array}$ & $\begin{array}{r}1998 \\
-99\end{array}$ & $\begin{array}{r}1999 \\
-00\end{array}$ & $\begin{array}{r}2000 \\
-01\end{array}$ & $\begin{array}{r}2001 \\
-02\end{array}$ & $\begin{array}{l}2002 \\
-03^{*}\end{array}$ \\
\hline $\begin{array}{c}\text { Harvested } \\
\text { area }\end{array}$ & $\begin{array}{c}1,000 \\
\text { hectares }\end{array}$ & 1003.4 & 911.3 & 941.9 & 926.3 & 794.7 & 751.6 & 783.7 & 881.9 & 776.3 & 482.8 \\
\hline Yield & $\begin{array}{l}\text { tons per } \\
\text { hectare }\end{array}$ & 32.4 & 26.1 & 31.7 & 30.5 & 30.0 & 33.4 & 34.3 & 31.0 & 33.4 & 34.8 \\
\hline $\begin{array}{c}\text { Cane } \\
\text { production }\end{array}$ & $\begin{array}{c}\text { million } \\
\text { tons }\end{array}$ & 32.5 & 23.8 & 29.8 & 28.2 & 23.8 & 25.1 & 26.9 & 27.3 & 25.9 & 16.8 \\
\hline
\end{tabular}

Table 4. Selected characteristics of sugarcane UBPCs, 1993-94 through 2002-03.

\begin{tabular}{|c|c|c|c|c|c|c|c|c|c|c|c|}
\hline Item & Unit & $\begin{array}{r}1993 \\
-94\end{array}$ & $\begin{array}{r}1994 \\
-95\end{array}$ & $\begin{array}{r}1995 \\
-96\end{array}$ & $\begin{array}{r}1996 \\
-97\end{array}$ & $\begin{array}{r}1997 \\
-98\end{array}$ & $\begin{array}{r}1998 \\
-99\end{array}$ & $\begin{array}{r}1999 \\
-00\end{array}$ & $\begin{array}{r}2000 \\
-01\end{array}$ & $\begin{array}{r}2001 \\
-02\end{array}$ & $\begin{array}{l}2002 \\
-03^{*}\end{array}$ \\
\hline $\begin{array}{l}\text { Cane } \\
\text { production } \\
\text { value }\end{array}$ & $\begin{array}{l}\text { million } \\
\text { pesos }\end{array}$ & 463.7 & 348.0 & 423.6 & 417.3 & 508.6 & 642.6 & 596.8 & 588.3 & 558.3 & 376.9 \\
\hline $\begin{array}{c}\text { Total } \\
\text { production } \\
\text { value }\end{array}$ & $\begin{array}{l}\text { million } \\
\text { pesos }\end{array}$ & 502 & 446 & 503 & 472 & 579 & 603 & 654 & 580 & 749 & 458 \\
\hline $\begin{array}{c}\text { Profitable } \\
\text { units }\end{array}$ & number & 1058 & 526 & 325 & 354 & 262 & 600 & 598 & 410 & 468 & 333 \\
\hline $\begin{array}{c}\text { Profitable } \\
\text { units }\end{array}$ & percent & 67.8 & 37.2 & 25.4 & 31.4 & 25.2 & 59.9 & 62.6 & 44.0 & 52.6 & 47.1 \\
\hline Members & 1,000 & 153.1 & 132.4 & 140.2 & 141.1 & 145.2 & 139.5 & 137.4 & 134.7 & 130.6 & 148.6 \\
\hline $\begin{array}{c}\text { Cane } \\
\text { productivity }\end{array}$ & $\begin{array}{l}\text { tons per } \\
\text { member }\end{array}$ & 221.6 & 185.0 & 212.6 & 199.9 & 163.9 & 179.9 & 195.8 & 176.7 & 203.7 & 113.1 \\
\hline $\begin{array}{c}\text { Total } \\
\text { productivity }\end{array}$ & $\begin{array}{l}\text { pesos } \\
\text { per } \\
\text { member }\end{array}$ & 3278 & 33701 & 3585 & 3344 & 3988 & 4321 & 4761 & 4303 & 5736 & 2536 \\
\hline
\end{tabular}


Evaluating the Performance of Cuba's Sugarcane Basic Units of Cooperative Production....

Table 5. Production costs, price of sugarcane, and cost/price ratios in sugarcane UBPCs, 1993-94 through 2002-03.

\begin{tabular}{|c|c|c|c|c|c|c|c|c|}
\hline Year & $\begin{array}{c}\text { Pre- } \\
\text { harvest }\end{array}$ & Harvest & Hauling & $\begin{array}{c}\text { Total } \\
\text { Variable }\end{array}$ & Overhead & $\begin{array}{l}\text { Total } \\
\text { Cost }\end{array}$ & $\begin{array}{c}\text { Price of } \\
\text { Cane }\end{array}$ & $\begin{array}{c}\text { Cost/Price } \\
\text { Ratio }\end{array}$ \\
\hline & \multicolumn{8}{|c|}{ Pesos/ton of sugarcane } \\
\hline 1993-94 & 6.50 & 4.76 & 1.61 & 12.87 & $\mathrm{~N} / \mathrm{A}$ & 12.86 & 14.32 & 0.90 \\
\hline 1994-95 & 10.14 & 6.84 & 2.00 & 18.98 & $\mathrm{~N} / \mathrm{A}$ & 18.98 & 14.32 & 1.32 \\
\hline $1995-96$ & 14.39 & 8.55 & 2.29 & 25.23 & $N / A$ & 25.23 & 14.32 & 1.76 \\
\hline $1996-97$ & 16.13 & 8.50 & 2.17 & 26.80 & $N / A$ & 26.80 & 14.32 & 1.87 \\
\hline $1997-98$ & 16.43 & 8.91 & 2.16 & 27.51 & $\mathrm{~N} / \mathrm{A}$ & 27.50 & 14.32 & 1.92 \\
\hline 1998-99 & 14.42 & 8.38 & 2.24 & 25.04 & $\mathrm{~N} / \mathrm{A}$ & 25.04 & 21.65 & 1.16 \\
\hline $1999-00$ & 14.46 & 6.97 & 2.03 & 23.46 & 2.24 & 25.70 & 21.65 & 1.19 \\
\hline $2000-01$ & 14.91 & 7.33 & 2.03 & 24.27 & 2.44 & 26.71 & 21.65 & 1.23 \\
\hline 2001-02 & 14.75 & 7.47 & 2.12 & 24.34 & 2.20 & 26.54 & 21.65 & 1.23 \\
\hline 2002-03 & 16.09 & 6.92 & 1.98 & 24.99 & 2.87 & 27.86 & 21.65 & 1.29 \\
\hline
\end{tabular}

